SHS Web of Conferences 12, 01101 (2014)

DOI: $10.1051 /$ shsconf/ 20141201101

(C) Owned by the authors, published by EDP Sciences, 2014

\title{
Empowering Local Communities through Tourism Entrepreneurship: The Case of Micro Tourism Entrepreneurs in Langkawi Island
}

\author{
Aleff Omar Shah Nordin ${ }^{1}$, Ku Azam Tuan Lonik ${ }^{2}$, Mastura Jaafar ${ }^{3}$ \\ ${ }^{1,2}$ School of Distance Education, Universiti Sains Malaysia, 11800, Penang, Malaysia \\ ${ }^{3}$ School of Housing, Building and Planning, Universiti Sains Malaysia, 11800, Penang, Malaysia
}

\begin{abstract}
The tourism sector has a huge effect in developing countries by providing immense economic opportunities to the local community. Entrepreneurship has been identified as essential actors for creating job opportunities, generating income, increasing standard of living and generally growing the economy. Using the random sampling approach, the questionnaires were distributed to the tourism entrepreneurs in the tourism attraction area in Langkawi Island. During the survey period, only a total of 263 entrepreneurs completed the questionnaires. The objective of this study is to explore the economic empowerment of the tourism entrepreneurship in contributing to income level, creating job opportunities and increasing standard of living. The findings of the study clearly show that the tourism entrepreneur activities contribute positively to income level, jobs, opportunities and standard of living of the local community.
\end{abstract}

\section{Introduction}

Empowerment has attracted the interest of those writing on tourism development. Empowerment also can be viewed as either a precursor to, or as both a cause and effect of community participation in tourism development [1]. The concept of empowerment has been a mainstay of alternative development approaches, especially in the tourism sector. In the context of tourism, empowerment refers to a process of enabling local communities to obtain the authority to gather resources to meet their needs, make decisions, take action and to achieve social justice [2]. The concept is supported by tourism developers who inspire to a bottom-up and participatory approach for development and those who are concerned about the western conduct of development that has been destroying resources and values [3].

In addition, in tourism sector, empowerment process can be viewed as the development of community [2]. Where development of tourism sector will encourage involvement of local community due to the existence of many employment opportunities offered in the tourism sector and increasing quality of life. According to [4], participation or involvement is not just about achieving more efficient and more equitable distribution of material resources. Participation includes sharing of knowledge and putting the process of learning itself in the service of the self-development of the people. As most of the tourism destinations are located in an inhabited rural area, empowerment is focussed to the local community in the area. Local communities benefited from the development of tourism industry in rural area through various activities related to the tourism. 
In the tourism literature, empowerment has been discussed in the context of endorsing the significance of community participation and sustainable tourism development [5]. Community participation can be seen as either an integral component of empowerment or as both a cause and an effect of empowerment [1]. It is usually recognized as being akin to local participation, in which local people are empowered to mobilize their own capacities, make decisions, control their resources and manage activities that affect their lives [6].

Specifically, the purpose of this research is to explore the extent of economic empowerment among the local communities through tourism entrepreneurial activities especially in rural area. The high level of community involving in tourism entrepreneurship leads to greater socio-economic benefits for the majority of local community tourism destination. This paper discusses the extent of the tourism entrepreneur contributing to the increasing in income level, creating job opportunities and improving standard of living among the local community.

\section{Economic empowerment through tourism entrepreneurship}

Economic empowerment in tourism sector can be defined by the tourism activities that bring lasting economic gains to a rural community [7]. This is characterized by the long term financial benefits to a destination community through tourism entrepreneurship. Entrepreneurship in a sustainable economic development strategy focuses on building wealth by supporting individual public and private entrepreneurs as they identify opportunities and gather resources to create and to grow their enterprises. Entrepreneurship is the willingness and ability of an individual to seek out investment opportunities, establish and run an enterprise successfully [8]. The entrepreneur is essentially a person who owns or controls a business through which income is gained. Onyebueke and Ochonogo (2002) site in [9] defined entrepreneurship as the art which involves recognizing a business opportunity, mobilizing resources and persisting to exploit that opportunity.

Entrepreneurship is the ability to seek investment opportunities and establish an enterprise based on identifying opportunities [10]. An entrepreneur is one who chooses or assumes risks, identifies business opportunities, gathers resources, initiates actions and establishes an organization or enterprise to meet such demand or market opportunity [11]. However, according to [8] entrepreneurship is the creation of products using the latest ideas and the ability to move resources from low productivity into the higher one to acquire profit, which consequently leads these entrepreneurs to be recognized for their effort in advancing society [12].

The rapid growth of the tourism industry has contributed to economic development through the generation of income for the population and increase employment opportunities. Through the tourism development, community have the opportunity to diversify their income by venturing into entrepreneur activities [13]. Support by [14] state that the economic impact of entrepreneurship is of enormous benefit to the economy. The economic empowerment through tourism entrepreneurship is very important in process in community development.

The community will benefit through entrepreneurship included fuelling economic growth with leads to increased income, the improvement of living standard, an increase in investment opportunities, the enlargement of the tax base, especially through formalization, technological development, skill development, and the creation of job opportunities. Therefore, it is noted that a higher level of community involved in tourism entrepreneurship will lead to a greater socio-economic benefit for the majority of the community. Economic empowerment is inclusive as empowerment will include of all people, women, elderlies, youth, people with disabilities, and people living in rural areas to involve in tourism entrepreneurship. 


\section{Research methodology}

\subsection{Respondents (setting and sampling)}

The data collection process took place on March 2014 involving 12 students from the University Sains Malaysia as interviewers. The research covered micro operators that operate at nine rural tourism attraction destinations in Langkawi Island namely, Kilim Geopark, Oriental Village, Makam Mahsuri, Cenang Beach, Air Hangat, Tanjung Rhu, Pantai Kok, Beras Terbakar, and Padang Matsirat. The booklet of questionnaires together with an introduction letter was brought together when the survey was carried out in order to get the cooperation of the entrepreneurs. Of the 300 questionnaire distributed only 263 gave responses representing $87.7 \%$ response rate. Before conducting the survey, the interviewers were briefed in detail to ensure that they understand the objectives of the study and the questions. The questionnaires consist of 87 questions and were divided into 5 sections, as follows: 1) Section A: Profile of the respondents; 2) Section B: Business background; 3) Section C: Business operations and management

\section{Research finding and discussions}

\subsection{Characteristics of respondent}

Table 1 shows the summary of the characteristics of 263 respondents (n-263) in term of gender, age, race, marital status, education level, dependents and household income. This tourism business is mostly owner by males, in which $53.2 \%$ (140) of the respondents are males and $46.8 \%(123)$ of them were female. The data on the tourism entrepreneur, age are separated into three main groups namely, young, medium-aged and elderly. Many of the tourism entrepreneurs age around 31 to 45 years old (38.4\%), follow by 46 to 60 years old (35.4\%), 22 to 30 years old (17.5\%), above 61 years old (5.3\%) and below 21 years old (3.4\%). Based on the age, most of the entrepreneurs involved in this tourism business were between 31 to 60 years old, which can be assumed as the pioneer group in this business. What concerns is the young entrepreneur below 21 years old in the tourism industry is very low $3.4 \%$. It is caused by several factors such as lack of knowledge, experience in the tourism business and young people prefer salaried jobs. Apart from that, capital factor also influences the young entrepreneur to entry in tourism business. Age of the entrepreneur is one of the success factor influences the survival of the business [15].

In terms of marital status, $81.8 \%$ of them were married and only $18.2 \%$ were single. From the race aspect, many of the respondents were Malay $89 \%$ (234) while $20 \%$ (20) were Chinese, $6 \%$ (2.3) were Indian and only $1.1 \%$ (3) was from a different ethnic. Essentially shows, a lot of Malays is occupied in rural area than the Chinese. The population history in Malaysia is the major factor Malays inhabiting in the rural and Chinese inhabiting in the city. Apart from that, based on statistics of total population in Langkawi in 2010 the majority of people in Langkawi were Malays $83.3 \%$. From the observation, most of the Chinese entrepreneurs run their business at Kuah Town in a big scale and Malay run small scale business in the rural area.

For the educational level, majority of tourism entrepreneurs $(59.3 \%)$ had secondary level education, about $16.3 \%$ had primary level education, $12.9 \%$ had diplomas, $8 \%$ had degree, $3 \%$ had no formal education and $0.4 \%$ had Masters. It was interesting that $78.6 \%$ of the respondents only had secondary or lower level of education and did not have any specialisation related to tourism but they could involve in tourism business because of the opportunities. There has been a study conducted to examine the relationship between educational level and success in entrepreneurship. Entrepreneur with high education usually have a broader view, initiative, and will to introduce new management [16]. On the other hand, there are also studies that show that no relationship exists between education and success in entrepreneurship. According to [18], there are also those have degrees but unable to 
perform the business. Nevertheless, concluded that formal education is not a significant factor in the success of the business in a small scale.

In term of the number of dependents, $4.2 \%$ of the respondents have no dependents. While the rest $95.8 \%$ of the respondent have between one to four dependents. Nevertheless, majority (46.4\%) of the entrepreneurs have dependents of four dependents. Regarding to the household income, respondents with income RM 2001-RM 4000 dominates 76\%, followed by RM 4001-RM 6000 with 12.5\%, RM $8001-\mathrm{RM} 10,000$ with $6.1 \%$, RM 6001-RM 8000 with $3 \%$ and the lowest is RM 10,000 and above with $2.3 \%$. What is a surprising, there are no respondent with household income below RM 2000 . That mean, the entire respondent out of the poverty line RM 700 in rural area (refer appendix for poverty line table in Malaysia). Poverty can be happen because of working with low income, high number of dependents, and unemployed [19]. Clearly shows that tourism business generates high income to the respondent and increase their standard of living. Besides that, through the tourism entrepreneur, local community have the opportunity to diversify their income by diversifying business opportunities in tourism sector especially in a rural area.

Table 1. Summary of respondent profile

\begin{tabular}{|c|c|c|c|}
\hline Description & Criteria & Frequency & $\begin{array}{c}\text { Percentage } \\
(\%)\end{array}$ \\
\hline \multirow[t]{2}{*}{ Gender } & Male & 140 & 53.2 \\
\hline & Female & 123 & 46.8 \\
\hline \multirow[t]{5}{*}{ Age } & $<21$ & 9 & 3.4 \\
\hline & $22-30$ & 46 & 17.5 \\
\hline & $31-45$ & 101 & 38.4 \\
\hline & $46-60$ & 93 & 35.4 \\
\hline & $61>$ & 14 & 5.3 \\
\hline \multirow[t]{4}{*}{ Race } & Malay & 234 & 89 \\
\hline & Chinese & 20 & 7.6 \\
\hline & India & 6 & 2.3 \\
\hline & Others & 3 & 1.1 \\
\hline \multirow[t]{4}{*}{ Marital Status } & Single & 31 & 11.8 \\
\hline & Married & 220 & 83.7 \\
\hline & Widow & 8 & 3 \\
\hline & Widower & 4 & 1.5 \\
\hline \multirow[t]{6}{*}{ Level of education } & No formal education & 8 & 3 \\
\hline & Primary school & 43 & 16.3 \\
\hline & Secondary school & 156 & 59.3 \\
\hline & Diploma & 34 & 12.9 \\
\hline & Undergraduate & 21 & 8 \\
\hline & Masters/PhD & 1 & 0.4 \\
\hline \multirow[t]{6}{*}{ No. of dependents } & No dependents & 11 & 4.2 \\
\hline & 1 & 28 & 10.6 \\
\hline & 2 & 42 & 16 \\
\hline & 3 & 60 & 22.8 \\
\hline & 4 & 122 & 46.4 \\
\hline & 5 and above & 0 & 0 \\
\hline \multirow[t]{6}{*}{ Household Income } & Below RM 2000 & 0 & 0 \\
\hline & RM 2001 - RM 4000 & 200 & 76 \\
\hline & RM 4001 - RM 6000 & 33 & 12.5 \\
\hline & RM 6001 - RM 8000 & 8 & 3 \\
\hline & RM 8001 - RM 10,000 & 16 & 6.1 \\
\hline & RM 10,001 and above & 6 & 2.3 \\
\hline
\end{tabular}




\subsection{Business Background}

Table 2 shows the respondent's business background. There are many types of tourism entrepreneurs such accommodation, transportation, attractions, tour operators and corporate planners [20]. However tourism businesses in Langkawi Island are divide into five main groups namely accommodation, transportation, services, entertainment, and supporting services. Majority of the respondents $37.3 \%$ are running the supporting services business (grocery store, laundry, cyber cafe, food and drink shops, bars and restaurants), followed by tourism service business (tourist guides, local sightseeing, scuba diving/snorkelling, souvenir shop, clothing shop, medications shop) 36.9\%, transportation business (cars rental, taxi, water taxi, travellers bus and etc.) $13.3 \%$, accommodation (hotel $/ \mathrm{motel} / \mathrm{resort}$, chalet/inns, homestay, guest range/lodges and others) $11 \%$ and the lowest is entertainment $1.5 \%$. Business on accommodation and entertainment are lowest because the initial capital to start-up the business is high. Besides that, entertainment business such pub, bar, and karaoke centre are not suitable in rural area to respect the local culture.

Table 2. Summary of business background

\begin{tabular}{llcc}
\hline \multicolumn{1}{c}{ Description } & \multicolumn{1}{c}{ Criteria } & Frequency & $\begin{array}{c}\text { Percentage } \\
\text { (\%) }\end{array}$ \\
\hline Types of business & Accommodation & 29 & 11 \\
& Transportation & 35 & 13.3 \\
& Services & 97 & 36.9 \\
& Entertainment & 4 & 1.5 \\
& Supporting services & 98 & 37.3 \\
\hline Year premises operate & 1990 and below & 3 & 1.1 \\
& $1991-2000$ & 79 & 30 \\
& 2001-2010 & 100 & 38 \\
& 2011 and above & 81 & 30.1 \\
\hline Starting a business & Family legacy & 31 & 11.8 \\
& Own initiative & 208 & 79.1 \\
& Sharing & 18 & 6.8 \\
& Cooperative & 6 & 2.3 \\
\hline Business Entities & Sole Proprietorship & 159 & 60.5 \\
& Partnership & 104 & 39.5 \\
\hline No. of business premises & 1 & 220 & 83.7 \\
owned & 2 & 28 & 10.6 \\
& 3 & 10 & 3.8 \\
& 4 & 4 & 1.5 \\
& More than 5 & 1 & 0.4 \\
\hline
\end{tabular}

In term of start-up time, majority of the premises existed during the period of $2001-201038 \%$ (100), followed by 2011 and above 30.1\% (81), 1991-2000 30\% (79) and while only 1.1\% existed before 1990. Most of the respondent started their business after 1990 because Langkawi Island experienced rapid grow after it was declared as a duty free island in 1987. Since becoming a duty free island, local community previously employed in agriculture as farmers and fishermen have taken the opportunity to get involved in business activity related to the tourism sector. It was interesting to note that every year tourism business shows an amazing enhancement. Even in year 2011 until 2014 the number of premise exists was strongly encourages and expected will continue increase.

Majority of the respondent start their business with own initiative 79.1\% (208) followed by those from family inheritance with $11.8 \%$ (31), sharing (sharing with family or friend) with $6.8 \%$ (18), and cooperative with $2.3 \%$ (6). While, in term of business entities, majority $60.05 \%$ (159) is sole 
proprietors and the rest 39.05\% (104) as partnerships. Majority of the respondents $83.7 \%$ (117) own only one business premise followed by those owning two business premises $10.6 \%(28), 3.8 \%$ (10) owning three business premises, while those owning business premise from $1.5 \%$ (4) and only one of the respondents has more than five business premises $0.4 \%$.

\subsection{Business Start-up and Financial Sources}

Table 3 shows the business financial characteristics of the respondent consist of sources of capital to start business, loan, capital to start business and income. Majority of the respondents preferred to use their own capital to start-up business. From the result, a majority of the respondents used their own saving as a capital to start their businesses 53.6\% (141), while others $46.4 \%$ (122) depend on loan to start-up business. From $46.4 \%$ of the respondents who depend on loan, $19.4 \%$ (51) take loans from banks to start-up business, $14.8 \%$ (39) take loans from government agencies (TEKUN, AIM, MARA, and etc.), $8.7 \%$ (23) borrow from families and friends, and 3.4\% (9) obtain loan from cooperatives. For the financial sources, the owner-managers relied on the strong ties with family members to back up their early business start-up. Difficulties in accessing loans from bank and others financial sources were the main reason for most of the respondents to depend on own saving to start-up business. Moreover, getting loan from banks require many procedures that they could not afford to fulfil such as requiring guarantors, collateral and strong financial support (McGrath, 1987). In addition, micro and small entrepreneurs also do not the ways and other sources to get loans.

Table 3. Summary of business characteristics

\begin{tabular}{llcc}
\hline \multicolumn{1}{c}{ Description } & \multicolumn{1}{c}{ Criteria } & Frequency & $\begin{array}{c}\text { Percentage } \\
\text { (\%) }\end{array}$ \\
\hline Sources of capital to start & Own saving & 141 & 53.6 \\
business & Cooperative loan & 9 & 3.4 \\
& Commercial bank loan & 51 & 19.4 \\
& Loan from family \& friends & 23 & 8.7 \\
& Government agencies & 39 & 14.8 \\
\hline Loan amount & RM 25,000 and below & 67 & 54.9 \\
& RM 25,001-RM 50,000 & 40 & 32.8 \\
& RM 50,001-RM 75,000 & 11 & 9 \\
& RM 75,001-RM 100,000 & 2 & 1.6 \\
& RM 100,001 and above & 2 & 1.6 \\
\hline Capital to start business & RM 5000 and below & 56 & 21.3 \\
& RM 5001-RM 10,000 & 47 & 17.9 \\
& RM 10,001-RM 15,000 & 36 & 13.7 \\
& RM 15001-RM 20,000 & 30 & 11.4 \\
& RM 20,001 and above & 94 & 35.7 \\
\hline Business income & Below RM 2000 & 0 & 0 \\
& RM 2001-RM 3000 & 142 & 54 \\
& RM 3001-RM 4000 & 56 & 6.8 \\
& RM 4001-RM 5000 & 18 & 17.9 \\
\hline
\end{tabular}

Regarding to the loan amount, from 122 respondents who take up loans, majority, $54.9 \%$ (67) take loans amounting to RM 25,000 and below, followed by loan amount of RM 25,001-RM 50,000 by $32.8 \%$ (40), loan amount of RM 50,001-RM 75,000 by $9 \%$ (11), loan amount of RM 75,001-RM 100,000 and RM 100,001 and above each by $1.6 \%$ (2). The loan are used either as initial capital to start-up business or for business expansion. Generally, a small and micro business operation does not 
require a huge initial capital to start-up the business knowledge, experience, skills, talents and selfreliant. Besides, the loan or micro finance is very important for small and micro entrepreneur in economic empowerment process.

In case of small and micro tourism business in Langkawi Island, 64.3\% (169) of the respondents start their businesses with capital of less than RM 20,000 and the rest, 35.7\% (94) start-up capital is RM 20,001 and above. The initial capital to start up business depends on type of business. Most of the respondents with start-up capital of RM 20,001 and above are involved with businesses related to accommodation, transportation and water base activities. In term of income from business, the majority of the respondents, 54\% (142) are earning between RM 2001-RM 3000, followed by RM 3001 -RM 4000 with $21.3 \%$ (56), RM 5001-and above with $17.9 \%$ (47) and the lowest income group are RM 4001-RM 5000 with $6.8 \%$ (18). Finding shows that no respondent gain income below RM 2000. This clearly shows that tourism business produces substantial income and is profitable. This finding is in line with most of the literature on economic empowerment focusing on poverty reduction among the community [21].

Table 1.5 explains the type of business contributing to the number of workers. Employment is one of the most readily available indicators to begin measuring economic empowerment in tourism industry. Majority of the respondents hire one or two workers to operate their business (185 respondents), followed by three to four workers (40 respondents), five to six workers (29 respondents), seven to eight workers (6 respondents), and the only three respondents do not employ any worker. From the analysis, it can be said that most of the respondents produce at least one number of worker. This finding is in line with that of many previous studies in the economic empowerment where entrepreneurship activities contributed a lot of job opportunities to the local communities [22]. Job creation generally helps to increases standards of living, increased in income and related socioeconomic progress [23]. Local community will benefit from the employment opportunities offered from the tourism activities and opportunity to increase their income and standard of living [24].

Table 4. Summary of type of business vs worker

\begin{tabular}{lcccccc}
\hline Type of Business & \multicolumn{7}{c}{ No. of Workers } \\
\cline { 2 - 7 } & $\begin{array}{c}\text { No } \\
\text { Worker }\end{array}$ & $1-2$ & $3-4$ & $5-6$ & $7-8$ & Total \\
\hline Accommodation & 0 & 13 & 9 & 4 & 3 & 29 \\
Transportation & 1 & 20 & 8 & 6 & 0 & 35 \\
Tourism Services & 1 & 77 & 4 & 12 & 3 & 97 \\
Entertainment & 0 & 4 & 0 & 0 & 0 & 4 \\
Supporting Services & 1 & 71 & 19 & 7 & 0 & 98 \\
\hline Total & 3 & 185 & 40 & 29 & 6 & 263 \\
\hline
\end{tabular}

\section{Conclusion}

The objective of economic empowerment is to increase income level, creating jobs opportunities and increasing standard of living. Based on empirical findings and literature reviews carried out in these studies, clearly shows that economic empowerment through tourism entrepreneur has been increasing the income level of local community. All 263 of respondents have income level more than RM 2000 and indirectly have lifted them out from the poverty gap (RM 650) in rural area. These finding is in line with [25], that tourism business tourism can create direct or indirect income from tourist expenditure by providing tourist goods and services. Apart from that, tourism entrepreneur also create job opportunities to the local community. Tourism entrepreneur in Langkawi Island offer at least one to two job opportunities. Majority of the respondents $(70 \%)$ have one or two workers to operate their business. In addition, majority of the workers belong to the local community. These finding is similar 
with [23] who states that a tourism business is one of the economic activities that contributes a lot of job opportunities to the local communities. Regarding to the standard of living, if members of the local community obtain a better jobs and bearable incomes from the tourism activities, their standard of living also will be increased. Developments of tourism industry enable the community to have opportunities to enhance their capabilities and skills to participate especially in tourism entrepreneurial and able to increase income level, employment opportunities and thus increase their standard of living [26]. Generally, tourism entrepreneurship is the catalyst to boost the economics of local community, increase income and employment opportunities for the local community to increase their standard of living.

\section{References}

1. D.D. Perkins, B.B. Brown \& R.B. Taylor. The ecology of empowerment: Predicting participation in community organizations. Journal of Social Issue, 52,1, 85 (1996)

2. D.J. Timothy. Empowerment and stakeholder participation in tourism destination communities. In: A. Church and T. Cole (Ed.) Tourism, Power and Space, London and New York: Routledge, 199-216 (2007)

3. R. Scheyvens. Tourism for development: empowering communities, Essex, England, Pearson Education Limited (2002)

4. D. Connell. Participatory Development: An Approach Sensitive to Class and Gender. Development in Practice, 7, 3, 248- 259 (1997)

5. H. Zeppel. Indigenous ecotourism: sustainable development and management. Wallingford: CABI (2006)

6. T.H.B. Sofield. Empowerment for Sustainable Tourism Development. Oxford: Elsevier Science. (2003)

7. R. Scheyvens. Ecotourism and the empowerment of local communities. Tourist Management, 20, 245-249 (1999)

8. J. Kokkranikal \& A. Morrison. Entrepreneurship and sustainable tourism: The houseboats of Kerala. Tourism and Hospitality Research, 4, 1, 7-20 (2002)

9. J.I. Oviawe. Repositioning Nigerian Youths for Economic Empowerment through Entrepreneurship Education. European Journal of Educational Studies 2, 2, 2010

10. Gana, Jonah Sheshi Suman, Entrepreneurship, Jofegan Associates, Kaduna (2001)

11. I.L. Anyakoha. Practical Tips for Economic Empowerment and Survival, Nsukka: AP Express (2006)

12. G. Dees. The meaning if social entrepreneurship. Retrieved from http://gsb.stanford.edu/csi/SEDefinition.html (1999)

13. O. Pazim and M. Mohd. Rosli, The Impact of Tourism on Small Business Performance: Empirical Evidence from Malaysian Islands. International Journal of Business and Social Science. $2,1,11-21$

14. G. Nieman and C. Nieuwenhuizen. Female entrepreneur in the hospitality trade: A case study in South Africa (1997)

15. A.M. Azmi, O. Nik Hairi \& Y. Lee Kuan. Critical Success Factors among Entreprenuers in Business. Journal of Social Sciences and Humanities. 7,1, (2012)

16. T. Bates. Entrepreneur human capital inputs and small business longevity. Review of Economics and Statistics, 72, 551-559 (1990)

17. M.J. Osirim. Characteristics of Entrepreneurship in Nigerian Industries That Started Small, PhD dissertation, Harvard University, United States - Massachusetts. Retrieved August 10, 2010 from Dissertations and Theses: Full Text. (Publication No. AAT 9035529. (1990)

18. R. Stuart and P.A. Abetti. "Field study of technical ventures-Part III: The Impact of Entrepreneurial and Management Experience on Early Performance." Frontiers of Entrepreneurship Research. B.A. Kirchoff, W.W. Long, W.E. McMullan, K.H. Vesper and W.E. 
19. Nor Aini Haji Idris. Program Pembasmian Kemiskinan Dalam Kalangan Ibu Tunggal: Analisis Penyertaan Dan Keberkesanan. Prosiding PERKEM VII, jilid 1 (2012) 248 - 259 (2008)

20. A. Robb and D. Robinson, The capital structure decisions of new firms. Review of Financial Studies, forthcoming (2012)

21. Vasanthakumari. Economic Empowerment of Women through Micro Enterprises in India with Special Reference to Promotional Agencies, International Journal of Multidisciplinary Research, Vol.2 Issue 1, January 2012

22. Zanisah Man, Nurul Fatanah Zahari, \& Mustaffa Omar, (2009) Kesan ekonomi pelancongan terhadap komuniti batek di Kuala Tahan, Pahang. Jurnal Sains Sosial dan Kemanusiaan, 4 ,1, 1$12(2009)$

23. S.E. Sanggin. Community Involvement in Culture and Nature Tourism in Sarawak, Akademika 77, 149-165 (2009)

24. S. Akis, N. Peristianis \& J. Warner. Residents' Attitudes to Tourism Development: The Case Of Cyprus. Tourism Management, 17, 7, 481-494 (1996)

25. S. Vijayanand. Socio-economic impacts in pilgrimage tourism. Zenith International Journal of Multidisciplinary Research 2, 1, 329-343 (2012)

26. G. McGrath. Managing the service encounter: consistent high-quality delivery through 'internal marketing'. In The International Marketing of Travel and Tourism- A Strategic Approach (L. Becherel, and F Vellas, Eds.). New York: Palgrave Macmillan (1999) 